\title{
Bone Marrow-Derived Mesenchymal Stem cells Infusion Ameliorates Hyperglycemia, Dyslipidemia, Liver and Kidney Functions in Diabetic Rats
}

\author{
Farozia Mousa $^{1}$, Karolin Kamel Abdel-Aziz ${ }^{2}$, Horeya Abdel Gawad ${ }^{3}$, Salwa Soliman Mahmoud ${ }^{4}$, Mahmoud \\ Saeed Elgamel ${ }^{5}$ \\ ${ }^{1,3,4,5}$ Department of Zoology, Faculty of Science, Alexandria University, Alexandria, Egypt \\ ${ }^{2}$ Department of Zoology, Faculty of Science, Damnhour University, Egypt
}

\begin{abstract}
Diabetes mellitus is associated with hyperglycemia, lipoprotein abnormalities and various organs dysfunctions. Stem cell therapy offers a great promise for the repair of injured tissues and organs. The aim of this study was to explore the effects of mesenchymal stem cell derived from bone marrow of albino rats on hyperglycemia, hypoinsulinemia, dyslipidemia and liver and kidney dysfunctions in STZ diabetic rats. Rat bone marrow mesenchymal stem cells (BM-MSCs) were isolated, cultured, characterized and finally injected intravenously $\left(2 \times 10^{6}\right.$, via tail vein) into STZ-induced diabetic rats. The other diabetic (STZ) rats received no treatment. The diabetic $(S T Z)$ rats showed significant $(P<0.05)$ increase in serum glucose, HbAlc, insulin resistance $(I R)$, total cholesterol, TGs, LDL-C, VLDL-C levels and a significant decrease of serum insulin, HDL-C levels as compared to their corresponding control. Also, higher levels of liver function tests (ALT, AST \& ALP) as well as kidney function tests (urea, uric acid and creatinine) were noticed in diabetic rats when compared to control group. Treatment of diabetic rats with MSCs significantly prevented these alterations. These data indicate the efficacy of MSCs transplantation in improving hyperglycemia, dyslipidemia, liver and kidney functions in diabetes mellitus. Further work is required to examine the curative effects on larger animal models and humans.
\end{abstract}

Keywords: Bone marrow, Mesenchymal stem cell, Streptozotocin, Diabetes, Dyslipidemia.

\section{Introduction}

Diabetes mellitus (DM) is the fourth or fifth cause of death in most countries. Each year, diabetes affects more people and causes more deaths than breast cancer and AIDS combined. In 2013, it was estimated that almost 382 million people world wide suffer from diabetes and the number is expected to grow beyond 592 million by 2035 [1].

Streptozotocin (STZ) is one of the animal models that mimic Type I DM in human which is characterized by hyperglycemia, alteration in carbohydrate and lipid metabolism as well as hypoinsulinemia due to marked defect in beta-cell mass causing insufficient insulin secretion [2].

Currently, there is no permanent cure for diabetes. People with type 1 diabetes must take insulin several times a day and test their blood glucose concentration three to four times a day [3]. However, there is a considerable success in insulin independency of diabetic patient after transplantation of whole pancreas or the islet cells. The transplantation strategy of treatment is greatly limited because human cadaver pancreases as well as pancreatic islet for transplantation will never be sufficient source for the replacement therapy for the millions of patients who suffer from this disease [4]. These highlight the need for new sources of islet cells. Stem cell transplantation represents one of the promising beta-cell replacement therapy [5].

The bone marrow in addition to haemopoietic stem cells comprises a population of mesenchymal stem cells, these cells exhibit multilineage differentiation capacity [6]. By using MSCs, we are thus using the "mother cell" from which pancreas and other tissues were originally derived [7], [8]. MSCs have several characteristics distinguish them from other cell types. First, they are undifferentiated cells that renew themselves for long periods through cell division, resulting in considerable amplification of stem cell number. Second, under certain physiologic or experimental conditions, they can be induced to become cells with special functions as pancreatic cells, cardiomyocyte, hepatocytes,..etc. Also, they have the ability to home to injured tissue causing tissue regeneration [9], [10].

To investigate the possible therapeutic effects of MSCs infusion in diabetic rats, we induced type 1 diabetes in rats by STZ injection and then measured the effect of single intravenous injection of MSCs on carbohydrate metabolism parameters, lipid profile, and liver and kidney function tests.

\section{Materials and Methods}

\subsection{Experimental Animals}

The experiment was carried out on 30 adult healthy female rats weighing $190 \pm 20 \mathrm{~g}$ and 10 young (6-7) weeks -old albino rats from which bone marrow mesenchymal stem cell (MSCs) were isolated. Animal were purchased from the animal house of the faculty of Medicine Mansoura University. The animals were housed in standard stainless steel cages at room temperature $25-28^{\circ} \mathrm{C}$, humidity of (50$60 \%$ ) and maintained at $12 \mathrm{hrs}$ alternating day and night cycle. The rats were fed standard diet and had free access to water. The rats were acclimatized to their housing and feeding for two weeks before the start of the experiment. The local committee approved the design of the experiments and 


\section{International Journal of Science and Research (IJSR) \\ ISSN (Online): 2319-7064}

Index Copernicus Value (2013): 6.14 | Impact Factor (2014): 5.611

the protocols were carried out according to the guidelines of the National Institutes of Health $(\mathrm{NIH})$.

\subsection{Induction of Diabetes}

DM was induced in 20 female rats by a single intraperitoneal injection of freshly prepared STZ (Sigma-Aldrich Chemical Company, St. Louis, Mo, USA)) supplied in powder form dissolved in citrate buffer $(10 \mathrm{ml}$ distilled water $+100 \mathrm{mg}$ citric acid $+180 \mathrm{mg}$ sodium citrate) in a dose of $65 \mathrm{mg} / \mathrm{kg}$. After 72 hours non-fasting blood glucose were measured to ensure the occurrence of DM. Rats with non-fasting blood glucose level more than $300 \mathrm{mg} / \mathrm{dl}$ were considered diabetes and were used in this study [11].

\subsection{Preparation of Complete Culture Medium}

To prepare the complete cultured medium, $10 \%$ of fetal bovine serum (Sigma- Aldrich CO., Germany) and 1\% Penicillin-Streptomycin solution (Sigma- Aldrich CO., Germany) were added to $89 \%$ Dulbecco's modified Eagle's medium ((Sigma- Aldrich CO., Germany) [12].

\subsection{Isolation and Expansion of Rat Bone Marrow MSCs}

Under sterile condition, bone marrow (BM) was collected by flushing the tibiae and femurs of 10 young (6-7) weeks -old albino rats with the previously prepared complete culture medium. Nucleated cells were isolated with a density gradient (Ficoll-Paque, Pharmacia) and resuspended in complete culture media. The cells were incubated in a standard CO2 incubator (SHEL- LAB CO2 Incubator) at 37 ${ }^{\circ} \mathrm{C}$ in $5 \%$ humidified $\mathrm{CO} 2$ for $12-14$ days as primary culture. Once the cells became confluent, they were washed twice with phosphate-buffered saline (PBS), and the cells then were trypsinized with $2.5 \mathrm{ml}$ of Trypsin-EDTA (purchased from Lonza Company) for $1-2 \mathrm{~min}$ at $37^{\circ} \mathrm{C}$. Then $10 \mathrm{ml}$ of complete culture medium was added to stop the action of Trypsin-EDTA. After centrifugation, the cells were resuspend in complete culture medium an incubated in 75$\mathrm{cm} 2$ tissue culture flasks (purchased from NUNC Company) for a further days, to reach $80-90 \%$ confluence. The resulting cultures were named first passage cultures. This step was repeated for a second passage. [13], [14]. Cell count and viability was determined using Neubauer improved hemocytometer and trypan blue [15].

\subsection{Morphological Characterization of MSCs}

Daily examination of the cultured cell was done during primary culture and the subsequent passages using inverted microscope (OLYMPUS-CKX41) [16]. On day 2 of the first passage, one of the incubated tissue culture flask was taken to apply giemsa stain (purchased from Biodiagnostic, Egypt) on its adherent cells according to Wang et al. [17]. Photographs were then taken by using the inverted microscope. The cells then had the appearance of fibroblast cells.

\subsection{Phenotyping Characterization of MSCs}

To ensure the exclusion of BM-hematopoietic stem cells and purity of BM-MSCs before being injected into diabetic rats, cells at passage 3 were trypsinized, centrifuged at $300 \mathrm{~g}$ for 8 minutes and resuspended in PBS at a concentration of 1 $\times 106$ cells $/ \mathrm{ml}$. $100 \mu \mathrm{L}$ aliquots were labeled (30mins) with antibodies against CD44, CD105, CD34 and CD31 phycoerythrin (PE) (supplied from Becton-Dickinson, USA), washed with $2 \mathrm{ml}$ of flow cytometry staining buffer (BD Pharmingen, USA), resuspended in $200 \mu \mathrm{L}$ of flow cytometry staining buffer for flow cytometric analysis using Flow cytometer (FACS Calibur, Becton Dickinson, USA) using using FACS calibur software [18], [19] .

\subsection{BM-MSCs Injection and Experimental Design}

Rats will divide randomly into three groups of 10 each as follows:

- Control group: 10 normal rats receive citrated buffer.

- Diabetic (STZ) group: 10 diabetic rats without treatment.

- Diabetic + Stem cell (STZ+ MSCs) group: 10 diabetic rats received i.v. injection (through tail vein) of $2 \times 10^{6}$ MSCs suspended into $0.2 \mathrm{~mL}$ physiological saline for each rat [20], for one time [21]. Similarly, for the control group and diabetic group, $0.2 \mathrm{~mL}$ of physiological saline was injected instead of MSCs.

After 15 days of stem cell infusion, rats were fasted for $12 \mathrm{~h}$ before being scarified then blood was collected for the determination of various biochemical parameters in the serum.

\subsection{Preparation of Serum}

The blood is collected into plain centrifuge tubes, then the blood was allowed to clot and the serum was separated from blood cells by centrifugation at $8000 \mathrm{rpm}$ for $5 \mathrm{~min}$ at $4^{\circ} \mathrm{C}$. The serum were separated and stored at $-20^{\circ} \mathrm{C}$ prior to biochemical analysis for determination of serum glucose, serum insulin, serum $\mathrm{HbA1c}$, lipid profile (TC, TG, HDL-C, LDL-C and VLDL-C), liver function tests (Serum ALT, AST \& ALP) and kidney function tests (Serum urea, uric acid and creatinine).

\subsection{Carbohydrate Metabolism Indicators Measurement}

Serum glucose level was estimated using commercially available kit (Glucose enzymatic colorimetric method, Biolabo, France) [22]. Glycated hemoglobin level (HbA1c) was assayed using kit purchased from Stanbio, U.S.A. according to the method of Klenk [23]. Insulin was assayed in serum samples by a solid phase enzyme-linked immunosorbent assay (ELISA) kit supplied by Biosource, Europe, was used according to the principles of method described by Frier et al. [24] . According to the homeostasis model assessment (HOMA-index), insulin resistance (IR) was calculated from the equation $\mathrm{IR}=$ [Glucose Conc. $(\mathrm{mmol} / \mathrm{L}) \times$ Insulin $(\mu \mathrm{IU} / \mathrm{L}) / 22.5$, whereas insulin 


\section{International Journal of Science and Research (IJSR) \\ ISSN (Online): 2319-7064}

Index Copernicus Value (2013): 6.14 $\mid$ Impact Factor (2014): 5.611

sensitivity index was calculated from the equation ISI $=1 /$ IR [25].

\subsection{Lipid Profile Measurement}

Serum TC and TGs level was measured by the colorimetric enzymatic assay using commercially available kits (Biolabo) France according to the methods introduced by Roeschlau et al. [26] and Polheim et al. [27], respectively. While, serum level of HDL-C was determined Using commercially available kit (Biolabo) France, according to method described by Rainwater et al. [28] for separation of HDL. The level of LDL-C was calculated from the equation LDLCholesterol level $=$ Total cholesterol - HDL - (Serum Triglyceride / 5), whereas, the level of VLDL-C was calculated according to the following equation VLDLCholesterol level $=$ Serum triglycerides (TGs) /5 [29].

\subsection{Liver Function Measurement}

Liver function was assessed by measurement of enzymatic activities of alanine transaminase (ALT) and aspartate transaminase (AST) according to the method of Reitman and Frankel [30], whereas serum alkaline phosphatase activity was measured according to Mathieu [31].

\subsection{Kidney Function Measurement}

Renal function was assessed by measurement of serum level of urea, uric acid and creatinine according to the methods of Young [32], Fossati et al. [33] and Henry [34], respectively.

\subsection{Statistical Analysis}

The values were expressed as mean \pm standard error (SE). The result were computed statistically using statistical Package for Social sciences (SPSS software package, version 19, Chicago, IL, USA) using one- way analysis of variance (ANOVA). $\mathrm{P}<0.05$ was considered as significant.

\section{Results}

\subsection{Morphological and Phenotyping Characterization of MSCs}

Isolated and cultured undifferentiated rat BM- derived MSCs reached $90 \%$ confluence at day 14 of primary culture showed purified population of spindle shaped cell that tightly adherent to the culture flask (Figure 1). Staining of cultured cell on day 2 of the first passage by giemsa stain showed 50\% confluent cells interconnected together with cytoplasmic process. Notice the cultured cells having bluish granular cytoplasm and vesicular nuclei. Some cells appear binucleated (Figure 2, 3).

In addition to characterization of the cultured cell as being MSCs by their morphology and adherence, they were characterized also by flow cytometric analysis which showed that these cells were positive for MSCs markers CD44 and CD105, while they are negative for endothelial cell marker CD31 and haematopoietic cell marker CD34 (Figure 4 A,B,C,D).

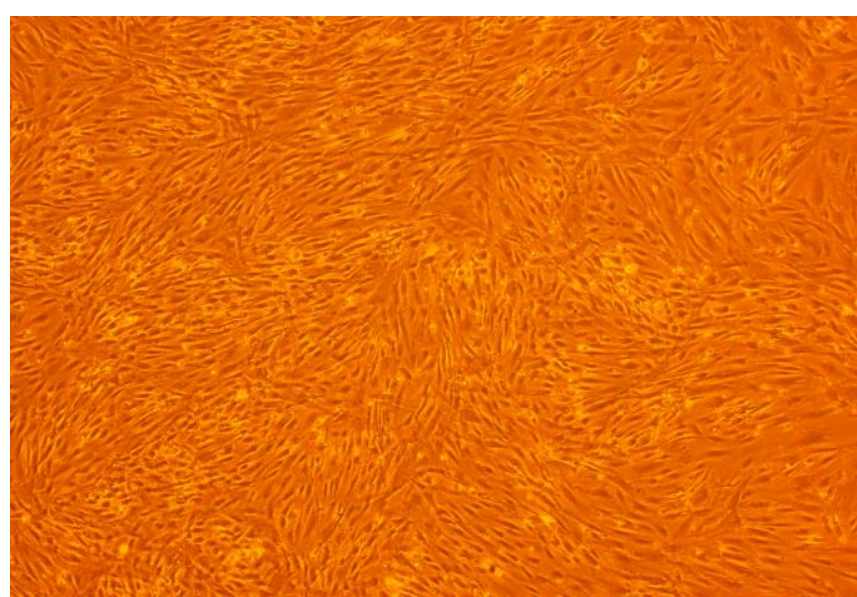

Figure 1: A photomicrograph of primary culture of rat BMMSCs (Day 14 of culture $\times 60$ ) showing purified population of spindle shaped cell. The cell reaches about $90 \%$ confluency.

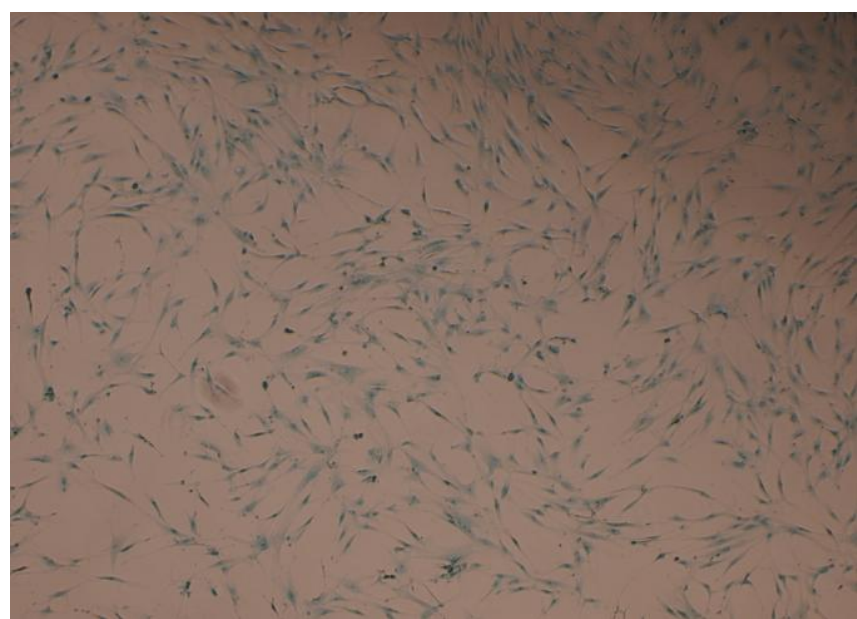

Figure 2: A photomicrograph of first passage of culture of rat BM-MSCs (Day 2 of culture: Gimesa Stain $\times 60$ ) showing spindle shaped cells, few flat polygonal and triangular shaped cells interconnected together with cytoplasmic process. The cultured cells reach approximately $50 \%$ confluency.

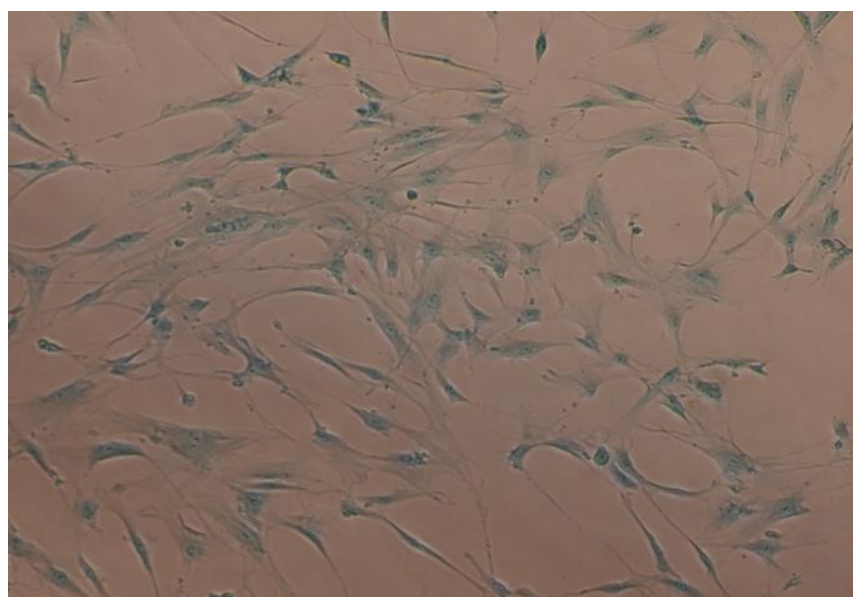

Figure 3: A photomicrograph of first passage of culture of rat bone marrow derived mesenchymal stem (Day 2 of culture: Gimesa Stain $\times 100$ ). Notice the cultured cells having bluish granular cytoplasm and vesicular nuclei. Some cells appear binucleated. 
International Journal of Science and Research (IJSR)

ISSN (Online): 2319-7064

Index Copernicus Value (2013): 6.14 $\mid$ Impact Factor (2014): 5.611
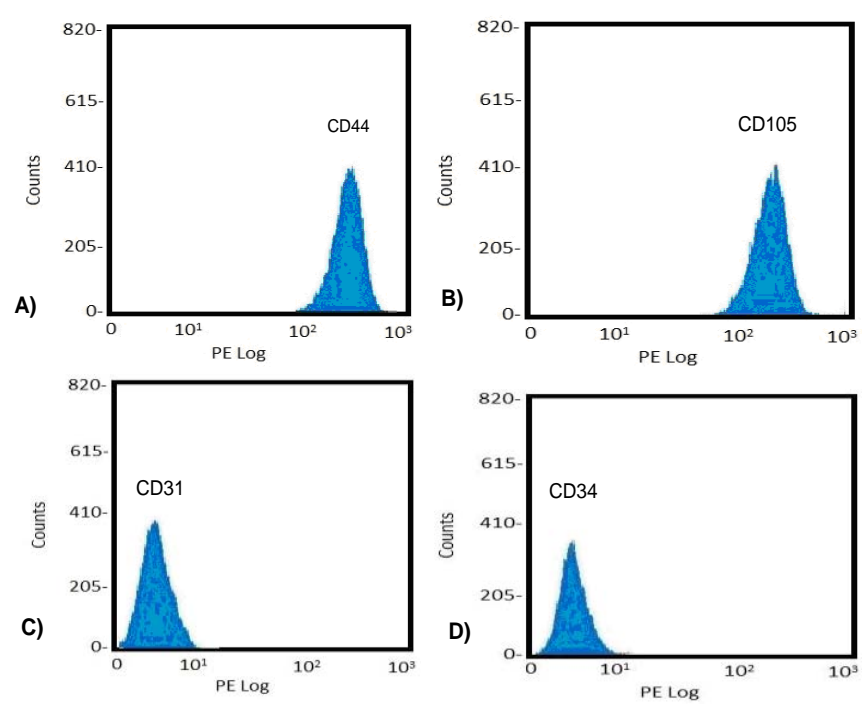

Figure 4: Flowcytometry of BM-MSCs showed the cell positive for: A) CD44 and, B) CD105 while negative for C) CD31, and D) CD34.

\subsection{Effects of MSCs on Carbohydrate Metabolism Indicators}

In untreated diabetic (STZ) group, levels of serum glucose, glycated hemoglobin as well as insulin resistance (IR) were significantly increased when compared with that of the control value, $\mathrm{P}<0.05$. However, diabetic group injected with mesenchymal stem cell (STZ+MSCs) revealed a significant decrease in levels of serum glucose, HbAlc and IR, when compared to that of untreated diabetic group, $\mathrm{P}<0.05$. Regarding to serum insulin level and insulin sensitivity index (ISI), untreated diabetic (STZ) group showed significant decrease of their values when compared with that of the control value, $\mathrm{P}<0.05$. However, $\mathrm{STZ}+\mathrm{MSC}$ group revealed a significant increase in serum insulin and ISI when compared to that of STZ group, $\mathrm{P}<0.05$, Table 1 .

Table 1: Effects of MSCs on serum glucose, glucaded hemoglobin, serum insulin, IR and ISI levels in diabetic rats

\begin{tabular}{|c|c|c|c|}
\hline \multirow{2}{*}{ Parameters } & \multicolumn{3}{|c|}{ Experimental groups } \\
\cline { 2 - 4 } & Control & STZ & STZ+MSCs \\
\hline Glucose $(\mathrm{mg} / \mathrm{dl})$ & $102.00 \pm 3.17$ & $468.60 \pm 11.25^{\mathrm{a}}$ & $112.60 \pm 3.43^{\mathrm{b}}$ \\
\hline HbA1C(\%) & $5.19 \pm 0.10$ & $8.60 \pm 0.24^{\mathrm{a}}$ & $5.50 \pm 0.25^{\mathrm{b}}$ \\
\hline Insulin level $(\mu \mathrm{IU} / \mathrm{ml})$ & $20.42 \pm 0.54$ & $7.40 \pm 0.27^{\mathrm{a}}$ & $14.67 \pm 0.30^{\mathrm{ab}}$ \\
\hline Insulin Resistance (IR) & $5.13 \pm 0.14$ & $8.54 \pm 0.26^{\mathrm{a}}$ & $4.07 \pm 0.14^{\mathrm{b}}$ \\
\hline $\begin{array}{c}\text { Insulin Sensitivity } \\
\text { Index (ISI) }\end{array}$ & $0.20 \pm 0.01$ & $0.12 \pm 0.001^{\mathrm{a}}$ & $0.25 \pm 0.01^{\mathrm{b}}$ \\
\hline
\end{tabular}

- Values represent the mean $\pm \mathrm{SE}$ of 6 samples.

- a means significantly different from control group at $\mathrm{P}<0.05$.

- $\mathrm{b}$ means significantly different from $\mathrm{STZ}$ group at $\mathrm{P}<0.05$.

\subsection{Effects of MSCs on Lipid Profile}

STZ-induced diabetic rats showed significant increase in Total cholesterol (TC), triglycerides (TGs), low density lipoprotein cholesterol (LDL-C) and very low density lipoprotein cholesterol (VLDL-C) and significant decrease high density lipoprotein colesterol (HDL-C) levels when compared to the control rats, $\mathrm{P}<0.05$. MSCs treatment of STZ-induced diabetic rats improved the alteration of lipid profile of diabetic rats, Table 2 .
Table 2: Effects of MSCs on serum lipid profile levels in diabetic rats

\begin{tabular}{|c|c|c|c|}
\hline \multirow{2}{*}{ Parameters } & \multicolumn{3}{|c|}{ Experimental groups } \\
\cline { 2 - 4 } & Control & STZ & STZ + MSCs \\
\hline $\begin{array}{c}\text { Total cholesterol } \\
(\mathrm{mg} / \mathrm{dl})\end{array}$ & $56.66 \pm 1.27$ & $114.9 \pm 5.74^{\mathrm{a}}$ & $60.22 \pm 1.12^{\mathrm{ab}}$ \\
\hline TGs $(\mathrm{mg} / \mathrm{dl})$ & $33.68 \pm 1.04$ & $109.6 \pm 5.72^{\mathrm{a}}$ & $32.66 \pm 0.49^{\mathrm{b}}$ \\
\hline HDL-C $(\mathrm{mg} / \mathrm{dl})$ & $28.08 \pm 0.52$ & $13.6 \pm 0.5^{\mathrm{a}}$ & $29.64 \pm 0.43^{\mathrm{b}}$ \\
\hline LDL-C $(\mathrm{mg} / \mathrm{dl})$ & $21.8 \pm 1.32$ & $79.4 . \pm 6.42^{\mathrm{a}}$ & $24.05 \pm 0.5^{\mathrm{ab}}$ \\
\hline VLDL-C $(\mathrm{mg} / \mathrm{dl})$ & $6.74 \pm 0.21$ & $21.92 \pm 1.14^{\mathrm{a}}$ & $6.53 \pm 0.10^{\mathrm{b}}$ \\
\hline
\end{tabular}

- Values represent the mean \pm SE of 6 samples.

- a means significantly different from control group at $\mathrm{P}<0.05$.

- $\mathrm{b}$ means significantly different from STZ group at $\mathrm{P}<0.05$.

\subsection{Effects of MSCs on Liver Function}

The results of this study showed a significant improvement in liver function. Serum alanine transaminase (ALT), aspartate transaminase (AST) alkaline phosphatase (ALP) enzymes activity were decreased in STZ+MSCs group compared to STZ group, $\mathrm{P}<0.05$, Table 3 .

Table 3: Effects of MSCs on serum ALT, AST and ALP levels in diabetic rats

\begin{tabular}{|c|c|c|c|}
\hline \multirow{2}{*}{ Parameters } & \multicolumn{3}{|c|}{ Experimental groups } \\
\cline { 2 - 4 } & Control & STZ & STZ + MSCs \\
\hline ALT (U/L) & $46.40 \pm 1.88$ & $141.60 \pm 2.59^{\mathrm{a}}$ & $56.60 \pm 1.75^{\mathrm{ab}}$ \\
\hline AST (U/L) & $73.20 \pm 1.81$ & $129.20 \pm 2.76^{\mathrm{a}}$ & $78.60 \pm 2.23^{\mathrm{b}}$ \\
\hline ALP (U/L) & $83.40 \pm 1.97$ & $154.20 \pm 2.70^{\mathrm{a}}$ & $92.20 \pm 1.43^{\mathrm{ab}}$ \\
\hline
\end{tabular}

- Values represent the mean \pm SE of 6 samples.

- a means significantly different from control group at $\mathrm{P}<0.05$.

- $\mathrm{b}$ means significantly different from STZ group at $\mathrm{P}<0.05$.

\subsection{Effects of MSCs on Kidney Function}

MSCs infusion improved kidney function. This was evidenced by decreased urea, uric acid and creatinine in $\mathrm{STZ}+\mathrm{MSC}$ group compared to STZ group, $\mathrm{P}<0.05$, Table 4 .

Table 4: Effects of MSCs on serum Urea, Uric acid and Creatinine levels in diabetic rats

\begin{tabular}{|c|c|c|c|}
\hline \multirow{2}{*}{ Parameters } & \multicolumn{3}{|c|}{ Experimental groups } \\
\cline { 2 - 4 } & Control & STZ & STZ+MSCs \\
\hline Urea $(\mathrm{mg} / \mathrm{dl})$ & $14.96 \pm 0.05$ & $23.28 \pm 0.21^{\mathrm{a}}$ & $16.92 \pm 0.13^{\mathrm{b}}$ \\
\hline Uric acid $(\mathrm{mg} / \mathrm{dl})$ & $3.33 \pm 0.11$ & $4.57 \pm 0.16^{\mathrm{a}}$ & $3.32 \pm 0.04^{\mathrm{b}}$ \\
\hline $\begin{array}{c}\text { Creatinine } \\
(\mathrm{mg} / \mathrm{dl})\end{array}$ & $0.49 \pm 0.13$ & $1.06 \pm 0.13^{\mathrm{a}}$ & $0.62 \pm 0.03^{\mathrm{ab}}$ \\
\hline
\end{tabular}

- Values represent the mean \pm SE of 6 samples.

- a means significantly different from control group at $\mathrm{P}<0.05$.

- $b$ means significantly different from STZ group at $\mathrm{P}<0.05$.

\section{Discussion}

Bone marrow-derived MSCs possess considerable potential towards development of cell-based therapeutic strategies for regenerative medicine and tissue repair. Because the ease of their isolation, their multilineage potential and their extensive propagation in vitro, they are among the first stem cell types to be introduced in the clinic [35].

MSCs are isolated from bone marrow mononuclear cells and separated from hematopoietic stem cells on the basis of their 


\section{International Journal of Science and Research (IJSR) \\ ISSN (Online): 2319-7064}

Index Copernicus Value (2013): 6.14 | Impact Factor (2014): 5.611

selective adherence to the culture surface [36]. In the present study, bone marrow derived MSCs were isolated from albino rats, cultured and characterized by their adhesiveness and spindle shape and by expressing the standard MSCs surface markers, CD44 and CD105, whereas they were negative for Hematopoietic cells and endothelial cells markers, CD34 and CD31 respectively. These were inline with other previous studies of several authors. [37][39].

The direct and persistence hyperglycemia and hypoinsulinemia in rats after STZ administration is due to the uptake of STZ by pancreatic B- cells via the glucose transporter GLUT2 [40],[41], following which STZ induces alkylation of the DNA of pancreatic beta cell via the nitrosourea moiety of this compound. Moreover, Zafar and Naqvi [42] and Saumya and Basha [43], reported that STZ decompose inside the cell to form carbonium ions that alkylate DNA and decrease cellular nicotinamide adenine nucleotide (NAD) level which may adversely affect beta cells by interrupting respiratory enzyme activity and alteration of their mitochondrial function leading to irreversible cellular necrosis and death of beta cells resulting in permanent hyperglucemia, this changes lead to suppression and disturbance of biosynthesis and insulin secretion. Moreover, Cemek et al. [44] also found that hyperglycemia is due to irreversible destruction of beta islet cells of the pancreas by STZ, causing a reduction of insulin secretion (hypoinsulinemia).

Our study also showed increased insulin resistance (IR) in diabetic (STZ) rats. Several other studies support the present finding that IR and Beta-cell dysfunction together underlie the development of diabetes [45], [46].

Glycated hemoglobin is produced by non-enzymatic condensation of glucose molecules with free amino acids on the globin component of hemoglobin. The higher level of glucose level lead to elevation in HbAlc [47]. Several reports indicated that the measurement of glucosylated derivatives of hemoglobin in blood provides a good indication of the efficacy of diabetic control [48], [49]

The clinical improvement and the antidiabetic effect of bone marrow mesenchymal stem cells detected in STZ + MSCs treated group compared to the diabetic (STZ) group was also reported by Lv et al. [50] who investigated the antidiabetic effect of the transplanted bone marrow mononuclear cells, and found that the blood glucose levels improved after 6 days of the transplantation due to regeneration and proliferation of new $\beta$-cells. While hess et al. [51] reported marked reduction of serum glucose occur as early as 4 days after transplantation of bone marrow derived cells into STZtreated mice due to stimulation of endogenous cells to proliferate and produce insulin. In accordance with our study, some evidences reported that single infusion of MSCs decrease blood glucose in STZ diabetic rats [52], [53]. Dong et al. [52] reported that MSCs homed to pancreas of recipient rats and transdifferentiated into insulin-producing cells.

The present results revealed significant increase of serum TC, TGs, LDL-C and VLDL-C. While the HDL-C (good cholesterol) showed a significant decrease in diabetic (STZ) rats in compared with control rats. These results are also agreement with komolafe et al. [54] and Radhika et al. [55]. They reported that hyperlipidemia is a recognized complication of DM characterized by increased levels of TC, TGs and phospholipids; and changes in lipoprotein composition. The pathogenesis of lipid metabolic disturbance is demonstrated on the base of deficiency of insulin or inadequate insulin efficiency through elevated free fatty acids (FFAs) mobilization from adipose tissue and secondary elevation of the FFAs level in the blood, through an increase in the conversation of FFAs to ketone bodies or through their incorporation into liver triglyceride and VLDL$\mathrm{C}$, and through diminished lipogenesis.

The current study, also showed the therapeutic effect of stem cell on dyslipidemic changes in STZ induced diabetic rats as evaluated by significant reduction of serum levels of TC, TGs, LDL-C , VLDL-C and significant increase level of HDL-C of STZ + MSCs group in compared with that of diabetic (STZ) group. In agreement with El-Tantawy, and Halem, [21], they found that treatment of type 1 diabetic rats with MSCs normalized lipid profile pattern.

Several workers have reported that STZ-induced diabetes mellitus and insulin deficiency lead to increased blood glucose and association between specific diabetic complications and disturbances in various tissues, such as liver dysfunction, diabetic nephropathy and cardiovascular diseases. Enzyme activities in the serum or tissues are often used as 'marker' to ascertain early toxic effects of administered foreign compounds to experimental animals [56]. ALP is a membrane bound enzyme while ALT and AST are cytosolic enzymes. These enzymes are highly concentrated in the liver and kidney and are only found in the serum in significant quantities when the cell membrane becomes leaky and even completely ruptured. A rise in serum level or decrease in tissue level of these intracellular enzymes is an index of damage to liver and kidney cells [57], [58]. Besides, the kidneys maintain optimum chemical composition of body fluids by acidification of urine and removal of metabolite wastes such as urea, uric acid and creatinine. In renal disease, the concentrations of these metabolites increase in blood [59].

Regarding liver dysfunction, the STZ-induced diabetic rat in our study developed symptoms of liver dysfunctions, as shown by elevated serum ALT, AST and ALP enzymes levels. This may be due to STZ impairs liver function, thus leading to leakage of these enzymes in the blood by STZ due to prevention of DNA synthesis in mammalian cells and prevents cellular reproduction by inhibiting the substrate binding to the DNA or inhibiting many of the enzymes involved in DNA synthesis [60]. Waer and Helmy [61] revealed that, diabetic hepatic injuries results from several agents and is not controllable only via inhibition of hyperglycemia. As Liver is one of the most important organs that maintains blood glucose levels within normal limits thus enhancement of blood sugar yield to imbalance of oxidationreduction reactions in hepatocytes, so that, hyperglycemia through increasing in advanced glycation end products (AGEs) facilities free radicals production via disturbance in

\section{Volume 5 Issue 2, February 2016}




\section{International Journal of Science and Research (IJSR) \\ ISSN (Online): 2319-7064}

Index Copernicus Value (2013): 6.14 | Impact Factor (2014): 5.611

ROS production. Recent studies showed the effect of oxidative stress in liver during DM, in both humans and rodents. Increased ROS generation in the liver of diabetic individuals has been involved in the progression of nonalcoholic fatty liver disease (NAFLD). As increased ROS levels are related to morphological changes in hepatocytes and liver DNA damage [62], [63].

Diabetic nephropathy (DN), one of the most serious micro vascular complications of diabetes, is a major cause of end stage renal disease that is reflected by proteinuria, decreased creatinine clearance, elevated urea, uric acid and creatinine levels [64], [65]. In the present study the STZ induced diabetic rats developed symptoms of renal dysfunction, as shown by elevated serum urea, uric acid and creatinine concentrations. Patel et al. [66] and Erejuwa et al. [67] suggested that DM leads to an elevation in the oxidative damage, considerable injury in the glomeruli, a marked increase in the protein glycosylation, disorders in matrix protein synthesis and increase in treansforming growth factors-beta (TGF- $\beta$ ). Mir et al. [68] postulated that the change changes in serum urea and creatinine of STZ diabetic animals could be attributed to the functional and/or morphological changes in the kidneys. Patel et al. [66] also explained the increased level of both serum urea and creatinie were due to hyperglycemia that causes osmotic diuresis and depletion of extracellular fluid volume. Furthermore, Sriram and Subramanian [49] showed that the impaired balance of nitrogen coupled with lowered protein synthesis leads to increased concentration of urea in blood. Also, diabetic oxidative stress induces elevation of the levels of urea and creatinine, which are considered as a significant markers of renal dysfunction.

Our result showed that administration of BM-MSCs in diabetic rats showed a significant improvement of their liver function tests (ALT, AST \& ALP) and kidney function tests (Urea, Uric acid \& Creatinine) in compared to diabetic group and this may be due to homing of MSCs to injured tissue causing its regeneration by its direct differentiation ability or by the paracrine factors released by MSCs exhibit protective organ-actions [69]-[71].

In agreement of our study, the result of Abdel Aziz et al. [72] (2014) showed a significant improvement in kidney function (serum urea and creatinine) in the diabetic nephropathy (DN) group treated intravenously with single dose of $10^{6} \mathrm{MSCs}$ per rat compared to DN group. They referred this improvement in kidney function in MSCs treated group to their paracrine action via different growth factors such as VEGF, TGF- $\beta$ and TNF- $\alpha$ and antiapoptotic effects via $\mathrm{Bax}$ and $\mathrm{Bcl} 2$ genes.

In conclusion, our results revealed that rat BM-MSCs have the capacity to differentiate into functional insulin producing cells which can be a source for cell therapy for DM. Furthermore, BM-MSCs are capable of improving dyslipidemia, liver and kidney function in diabetic rat. This may be helpful in the prevention of complications associated with DM. However, because our study is an animal study, these findings must be confirmed after further study, such as clinical trial, on human subject.

\section{References}

[1] IDF. (2013). the Global Burden. International Diabetes Federation. IDF Diabetes Atlas, 6th edn. Brussels, Belgium: International Diabetes Federation; 2:32-37.

[2] Lenzen S. (2007). Alloxan and streptozotocin diabetes. In: Peschke E (ed) Endokrinologie III Vorträge im Rahmen des Projektes Zeitstrukturen endokriner Systeme". [Endocrinology III lectures within the time structures of endocrine systems'project framework]. Abhandlung der Sächs. Akad. Wiss., Mathnaturwiss Klasse, Verlag der Sächsischen Akademie der Wissenschaften, Leipzig, commissioned by S. Hirzel Verlag, Stuttgart/Leipzig, 119138.

[3] Oliveria SA, Menditto LA, Ulcickas Yood M, Koo YH, Wells KE, McCarthy BD. (2007). Barriers to the initiation of and persistence with, insulin therapy. Curr Med Res Opin. 23(12):3105-3112.

[4] Gibly RF, Graham JG, Luo X, Lowe WJ, Hering BJ, Shea LD. (2011): Advancing islet transplantation: from engraftment to the immune response. Diabetologia. 54, 2494-2505.

[5] Farge D, Vinia-Vija L, Francois J, Vexiau R. (2008). Mesenchymal stem cell therapy perspectives for type 1 diabetes. Proc. Rom. Acad; 12: 59-70.

[6] Bosnakovski D, Mizunto M, Kim G, Takagi S, Okumura M, Fujinaga,T. (2005): Isolation and multilineage differentiation of bovine bone marrow mesenchymal stem cells. Cell Tissue Res; 319:243-53.

[7] Bianco P, Robey PG, Simmons PJ. (2008). Mesenchymal Stem Cells: Revisiting History, Concepts, and Assays. Cell Stem Cell.; 2(4): 313-319.

[8] Kuiper, Kathleen (2010). The Britannica Guide to Theories and Ideas That Changed the Modern World. New York, NY: Britannica Educational Pub. In association with Rosen Educational Services. pp. 28.

[9] Khattri S, Bhradwaj M. (2010). Stem cells: where the future lies. The Orthodontic Cyber Journal ;(1):1-20.

[10] NIH. (2016). Stem Cell Basics: Introduction: What are stem cells, and why are they important?. In Stem Cell Information [World Wide Web site].Bethesda, MD: National Institutes of Health (NIH), U.S. Department of Health and Human Services, [cited Sunday, January 03, 2016] Available:http://stemcells.nih.gov/info/basics/pages/ basics1.aspx.

[11] Pandhare B, Waran S, Mohite B, Khange G. (2012). Antihyperglycemic and lipid lowering potential of adenanthera pavonina linn. in streptozotocin induced diabetic rats. Orient pharm Exp Med; 12(3):197-203.

[12] Sun X, Jiang H, Yang, H. (2007).In vitro culture of bone marrow mesenchymal stem cells in rats and differentiation into retinal neural-like cells. Huazhong Univ. Sci., Tecnolog. Med. Sci.; 27(5):598-600.

[13] Lennon DP, Caplan AI. (2006). Isolation of rat marrowderived mesenchymal stem cells. Experimental Hematology; 34:1604-1607.

[14] Wang Y, Wang M, Zhang P, Song JJ, LI YP, Hou, SH, Huang C.(2008).Effect of transplanted mesenchymal stem cells from rats of different ages on the improvement of heart function after acute myocardial infarction.

[15] Paul TS, (1988). Methods of cell separation chapter two: Methods of cell counting and assaying cell viability, Laboratory techniques in biochemistry and molecular bilolgy, Elsevier, (18):7-17. 


\section{International Journal of Science and Research (IJSR) \\ ISSN (Online): 2319-7064}

Index Copernicus Value (2013): 6.14 | Impact Factor (2014): 5.611

[16] Nadri S, Soleiman M, Hosseni R, Massumi M, Atashi A, Izadbanah R. (2007).An efficient method for isolation of murine bone marrow mesenchymal stem cells. Inv Dev Biol; 51: 723-729.

[17] Wang X, Hisha H, Taketani S, Adachi Y, Li Q, Cui W, Cui Y, Wang J, Song C, Mizokami T, Okazaki S, Li Q, Fan T, Fan H, Lian Z, Gershwin ME, Ikehara S. (2006). Characterization of mesenchymal stem cells isolated from mouse fetal bone marrow. Stem Cells; 24(3):482-493.

[18] Carvalho JM, de Souza MK, Buccheri V, Rubens CV, Kerbauy J, de Oliveira JSR. (2009). CD34-positive cells and their subpopulations characterized by flow cytometry analyses on the bone marrow of healthy allogenic donors. Sao Paulo Med J; 127: 12-8.

[19] Martins AA, Paiva A, Morgado JM, Gomes A, Pais M.L. (2009). Quantification and immunophenotypic characterization of bone marrow and umbilical cord blood mesenchymal stem cells by multicolor flow cytometry. Transplant Proc; 41: 943-6.

[20] Si Y, Zhao Y, Hao H, Liu J, Guo Y, Mu Y, Shen J, Cheng Y, Fu X, Han W. (2012). Infusion of Mesenchymal stem cells Ameliorates Hyperglycemia in type 2 diabetic rats.Diabetes, (61):1616-1625.

[21] El-Tantawy WH, Haleem EN. (2014). Therapeutic effects of stem cell on hyperglycemia, hyperlipidemia, and oxidative stress in alloxan-treated rat. Mol Cell Biochem; 391:193-200.

[22] Barham D, Trinder P. (1972). An improved colour reagent for the determination of blood glucose by the oxidase system. Analyst. 97 (151):142-145.

[23] Klenk S. (1991). Glycosylated haemoglobin as monitoring of diabetes mellitus. Clinic. Chem., 28: 2088-2094.

[24] Frier BM, Ashby JP, Narin IM, Barid JD. (1981). Plasma insulin, C-peptide and glucogon concentrations in patients with insulin independent diabetes treated with chlorpropamide. Diabet. Metab. (7): 45-49.

[25] Matthews DR, Hosker JP, Rudenski AS, Naylor BA, Treacher DF, Turner, R.C. (1985). Homoeostasis model assessment: insulin resistance and beta-cell function from fasting plasma glucose and insulin concentration in man. Diabetologia, (28): 412-419.

[26] Roeschlau P, Brent E, Gruber W. (1974). Enzymatic determination of total cholesterol in serum. Z Klin Chem. Klin Biochem. (12): 226-229.

[27] Polheim D, David JS, Schultz FM, Wylie MB, Johnston JM (1973). Regulation of triglyceride biosynthesis in adipose and intestinal tissue. J Lipid Res. (14): 415-421.

[28] Rainwater DL, Blangero J, Moore PH, Shelledy WR, Dyer TD (1995). Genetic control of apolipoprotein A-I distribution among HDL subclasses. Atherosclerosis, (118): 307-317.

[29] Assman G, Jabs H, Kohnert U, Note W, Schriewer H. (1984). The relation between total cholesterol, triglycerides and cholesterol fraction in high and mild lipidemia. Clin.Chem. Acta., (140): 77-83.

[30] Reitman S, Frankel S. (1957). A colorimetric method for the determination of serum glutamic oxalacetic and glutamic pyruvic transaminases. Am J Clin Pathol; (28): 56-63.

[31] Mathieu M. (1980). In l'information scientifique du Biologist. Soc.Francaise Bid. Clin., 2(8).Paris.

[32] Young DS. (1990). Effects of drugs on clinical laboratory tests. AAGG Press Washington D.G. Supplement, 1:1991.

[33] Fossati P, Prencipe L, Berti G. (1980). Use of 3,5 dicloro2-hydroxy-benzenesulfonicacid/4 chromogenic system in direct enzymatic assay of uric acid in serumand urine. Clin.Chem. (26),227-231

[34] Henry RJ (1974): Clinical chemistry; principles and techniques, 2nd ed., Harper and Row, Hagerstown MD: P.819-831.

[35] Sudkamp NP (2007). Clinical applications of Mesenchymal Stem Cells. European Cells and Materials; 13(2):3.

[36] Soleimani M., Nadri S.A. (2009). A protocol for isolation and culture of mesenchymal stem cells from mouse bone marrow. Nature Protocols; 4(1):102-106.

[37] Calió ML, Marinho DS, Ko GM, Ribeiro RR, Carbonel AF, Oyama LM, Ormanji M, Guirao TP, Calió PL, Reis LA, Simões MJ, Lisbôa-Nascimento T, Ferreira AT, Bertoncini CRA. (2014). Transplantation of bone marrow mesenchymal stem cells decreases oxidative stress, apoptosis, and hippocampal damage in brain of a spontaneous stroke model. Free Radical Biology and Medicine (70): 141-154.

[38] Zhao QS, Xia N, Zhao N, Li M, Bi CL, Zhu Q, Qiao GF, Cheng Zf. (2014). Localization of Human Mesenchymal Stem Cells from Umbilical Cord Blood and Their Role in Repair of Diabetic Foot Ulcers in Rats. Int. J. Biol. Sci.; 10: 80-89.

[39] Draz N, Attalah MF, Shaheen HM, Abo Elkeir W. (2015). In Vitro Differentiation of Human Bone Marrow Stem Cells into Retinal Pigment Epithelium. American Journal of Bioscience and Bioengineering; 3(4-1): 51-55.

[40] Tjälve H, Wilander E, Johansson EB. (1976): Distribution of labelled streptozotocin in mice: uptake and retention in pancreatic islets. J Endocrinol 69: 455-456.

[41] Karunanayake EH, Baker JR, Christian RA, Hearse DJ, Mellows G. (1976). Autoradiographic study of the distribution and cellular uptake of (14C) streptozotocin in the rat. Diabetologia 12: 123-128.

[42] Zafar M, Naqvi S. (2010). Effects of STZ-induced diabetes on the relative weights of kidney, liver and pancreas in albino rats: A comperative study.Int. J. Morphol., 28 (1): 135-142

[43] Saumya SM, Basha P. (2011). Antioxidant effects of Lagerstroemia Speciosa Pers (Banaha) leaf extract in streptozotocin-induced diabetic mice. Ind J. Exper. Bio., 49: 125-131.

[44] Cemek M, Kang S, Simsek N, Buyukokuroglu ME, Konuk, M. (2008). Antihyperglycemic and antioxidative potential of matricaria chamomilla L. in streptozotocininduced diabetic rats. J.Nat. Med., 62(3):284-293.

[45] Raz I, Riddle MC, Rosenstock J, Buse JB, Inzucchi SE, Home PD, Del Prato S, Ferrannini E, Chan JC, Leiter LA, Leroith D, Defronzo R, Cefalu WT. (2013). Personalized management of hyperglycemia in type 2 diabetes: reflections from a Diabetes Care Editors' Expert Forum. Diabetes Care 36(6):1779-88.

[46] Kulkarni R, Acharya J, Ghaskadbi S, Goel P. (2014). Thresholds of Oxidative Stress in Newly Diagnosed Diabetic Patients on Intensive GlucoseControl Therapy. PLoS ONE 9(6): e100897:1-8.

[47] Beissuenger PJ, Healy JC, Shultz EK (1993). Glycosylated serum proteins and glycosylated hemoglobin in the assessment of glycemic control in IDDM and NIDDM. Diabetes, (43); 420-430

[48] Tembhurne SV, Sakarkar DM. (2010). Protective effect of Murraya Koenigii (L) leaves extract in streptozotocin induced diabetic rats involving possible antioxidant mechanism. J.Med.Plants Res., 4(22):2418-2423. 


\section{International Journal of Science and Research (IJSR) \\ ISSN (Online): 2319-7064}

Index Copernicus Value (2013): 6.14 | Impact Factor (2014): 5.611

[49] Sriram PG, Subramanian S. (2011). Fistin, a bioflavonoid ameliorates hyperglycemia in streptozotocin-induced experimental diabetes in rats. Inter. J. Pharmaceutical Sci. Review Res.,6 (1):68-74.

[50] Lv S, Cheng J, Sun A, Li J, Wang W, Guan G, Liu G, Su M. (2014). Mesenchymal stem cells transplantation ameliorates glomerular injury in streptozotocin-induced diabetic nephropathy in rats via inhibiting oxidative stress. Diabetes Res Clin Pract.;104(1):143-154.

[51] Hess D, Li L, Martin M, Sakano S, Hill D, Strutt B, Thyssen S, Gray DA, Bhatia M. (2003). Bone marrowderived stem cells initiate pancreatic regeneration. Nat Biotechnol 21: 763-770.

[52] Dong Q, Chen L, Gao G, Wang L, Song J, Chenc B, Xua Y, Suna, L.(2008). Allogeneic diabetic mesenchymal stem cells transplantation in streptozotocin-induced diabetic rat. Clin Invest Med ; 31 (6): E328-E337.

[53] Ezaquer FM, Ezaquer ME, Parrau DB, Carpio D, Yanez AJ, Conget PA 2008). Systemic administration of multipotent mesenchymal stromal cells reverts hyperglycemia and prevents nephropathy in type 1 diabetic mice. Biol Blood Marrow Transplant;14:631-640.

[54] Komolafe OA, Adeyemi DO, Adewole SO, Obuotor EM (2009). Streptozotocin-induced diabetes alerts the serum lipid profiles of adult wistar rats. Int. J. Cardiovascular Res., 7(1): 1540-2592.

[55] Radhika T, Mahendar P, Venkatesham A, Reddy ARN, Reddy YN, Sadanadom A, Christopher T. (2010). Hypoglycemic activity of red kino tree in normal and Streptozotocin-induced diabetic rats. Inter. J. Pharmacol., 6(3):301-305.

[56] Moss DW, Rosalki, S.B. (1986). Enzyme tests in diagnosis. Edward Arnold. London.; 88-93.

[57] Adesokan Ayoade A.; Oyewole Oluwole I. and Turay Babara MS. (2009). Kidney and Liver Function Parameters in Alloxan-Induced Diabetic Rats Treated with Aloe Barbadensis Juice Extract. Sierra Leone J. Biomed. Res.;1 (1): 33-37.

[58] Zafar M, Naeem-Ul-Hassan Naqvi S, Ahmed M, Kaimkhani ZA. (2009). Altered liver morphology and enzymes in streptozotocin induced diabetic rats. Int. J. Morphol., 27(3):719-725.

[59] Chandramohan G, Al-Numair KS, Pugalendi KV. (2009). Effect of 3-hydroxymethyl xylitol on hepatic and renal functional markers and protein levels in streptozotocin diabetic rats. Afr. J. Biochem. Res. 3(5):198-204.

[60] Holemans K, Bree RV, Verhaeghe J, Meurrens K, Assche AV (1997). Maternal Semi starvation and Streptozotocin-Diabetes in Rats have different effects on the in Vivo glucose uptake by peripheral tissues in their female adult offspring. The Journal of Nutrition 127: 1371-1376.

[61] Waer HF, Helmy SA. (2012). Cytological and Histochemical Studies in Rat Liver and Pancreas during Progression of Streptozotocin Induced Diabetes and Possible Protection of Certain Natural Antioxidants. J Nutr Food Sci 2(9):165-172.

[62] Cubero FJ, Trautwein C. (2011). Oxidative Stress and Liver Injury. In: Monga SP, editor. Molecular Pathology of Liver Diseases. London: Springer US.;427-435.

[63] Dechandt CRP, De Souza DLP, Siqueira JT, Pereira MP, De Assis RP, Da Silva VC, De Sousa Junior PT, Brunetti IL, Andrade CMB, Kawashita NH, Baviera AM. (2014). Changes in the Oxidative Stress Biomarkers in Liver of Streptozotocin-diabetic Rats Treated with Combretum lanceolatum Flowers Extract, British Journal of Pharmaceutical Research, 4(20): 2340-2356.

[64] Yan HD, Li XZ, Xie JM, Li M. (2007). Effects of advanced glycation end products on renal fibrosis and oxidative stress in cultured NRK-49F cells. Chin. Med. J., 120:787-793.

[65] Davey GC, Patil SB, O’Loughlin A, O’Brien, T. (2014). Mesenchymal stem cell-based treatment for microvascular and secondary complications of Diabetes mellitus. Front Endocrinol. 5: (86): 1-18.

[66] Patel SS, Shah RS, Goyal, RK. (2009). Antihyperglycemic, antihyperlipidemic and antioxidant effect of Dihar, a polyherbal an ayurvedic formulation in streptozotocin induced diabetic rat. I. J. Exp. Bio., 471:564-570.

[67] Erejuwa OO, Sulaiman SA., AB Wahab MS, Sirajudeen KNS, Salleh MSM, Guttu S. (2011). Glibenclamide or Metformin Combined with honey Improves Glycemic Control in Streptozotocin-Induced Diabetic Rats. Int. J. Biol. Sci., 7(2):244-252.

[68] Mir SH, Baqui A, Bhagat RC, Darzi MM, Shah AW. (2008). Biochemical and histomorpholgical study of streptozotocin-induced diabetes melliutus in rabbits. Pakistan J. Nutr., 7 (2): 359-364.

[69] Gnecchi M, He H, Melo LG, Noiseaux N, Morello F, de Boer RA, Zhang L, Pratt RE, Dzau VJ, Ingwall JS. (2009). Early beneficial effects of bone marrow- derived mesenchymal stem cells overexpressing Akt on cardiac metabolism after myocardial infarction. Stem Cells; 27: 971-979.

[70] Tögel FE, Westenfelder C. (2010). Mesenchymal stem cells: a new therapeutic tool for AKI. Nat Rev Nephrol ; 6 : 179-83.

[71] Xagorari A, Siotou E, Yiangou M, Tsolaki E, Bougiouklis D, Sakkas L, Fassas A, Anagnostopoulos A. (2013). Protective effect of mesenchymal stem cell-conditioned medium on hepatic cell apoptosis after acute liver injury. Int J Clin Exp Pathol.;6(5):831-840.

[72] Abdel Aziz MT, Wassef MAA., Ahmed HH, Rashed, L, Mahfouz, S. Aly MI, Hussein RE, Abdelaziz M. (2014). The role of bone marrow derived-mesenchymal stem cells in attenuation of kidney function in rats with diabetic nephropathy. Diabetology \& Metabolic Syndrome, 6:3444. 